\title{
Dordt and Pentecostal traditions: African 'Spiritual' Churches in South Africa today
}

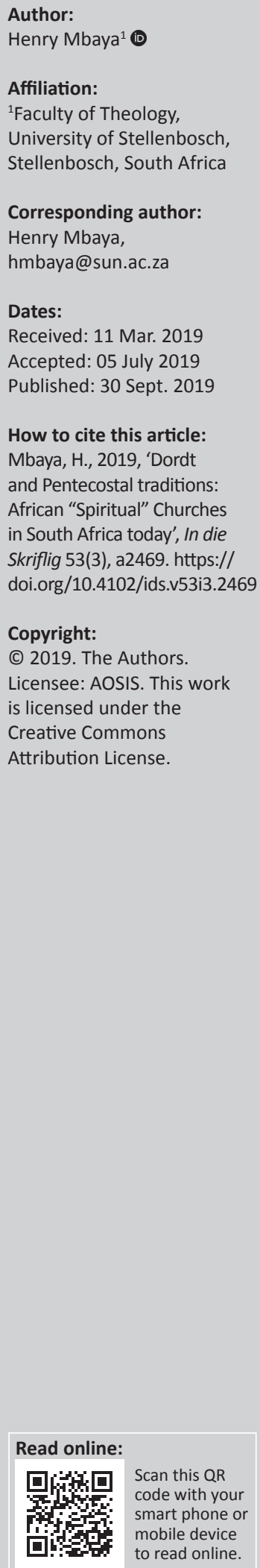

\begin{abstract}
This article explores the possible link between the teachings of the Canons of Dordt in the Netherlands (1618-1619) and those of the Pentecostal and African Spiritual Churches in South Africa today. This article tries to identify some common features as well as points of divergence between the two traditions, particularly with regard to the role of Scripture, divine sovereignty, and human responsibility in salvation. Secondly, this study highlights the views on the role of the Holy Spirit in election and salvation in relation to divine grace.

Keywords: African Traditions; Arminians; Canons; Christian; Doctrine; Dordt Synod; Dordrecht; Dutch; Pentecostalism; Reformed Faith; Salvation; Scripture.
\end{abstract}

\section{Introduction}

This year marks 400 years since the Synod of Dordt convened at Dordrecht in The Netherlands between 1618 and 1619. This article seeks to make a contribution to the debate about the significance of that event in light of Christianity in Southern Africa today.

As background to the discussion in the last half of this article, the introductory part highlights three perspectives from the Synod of Dordt. The first is the influence of Scripture and a scholastic tradition approach on issues of divine sovereignty and human responsibility in salvation. Secondly, this article probes the role of the Holy Spirit in election and salvation in relation to divine grace; and lastly, it considers the teachings of Dordt as an attempt to indigenise the Reformed faith on the Dutch soil.

The second part of this article very briefly highlights the role of the Dutch Reformed Church ministers Andrew Murray and in particular, his 'disciple', Piet le Roux, in the founding of the Pentecostal and African 'Spiritual' Churches in South Africa. The discussion then examines some common features as well as differences between Dordt and Pentecostal traditions and African 'Spiritual' Churches in light of the doctrinal issues and perspectives of Dordt developed in the first half of the essay. Firstly, I present a brief historical account of the Synod of Dordt.

\section{A brief historical background of the Synod}

Laura Cruz (2008) notes that, traditionally, the Netherlands existed as:

... a composite polity, consisting of a mishmash of duchies, counties, and lordships because the idea of
creating a kingdom or a king was not deemed practical, but some did seek to strengthen, or at least
maintain, a centralized rule. (p. 12)

During the war of national independence against Spain, its ruler, William of Orange, recognised the plurality of the religious feelings of the Dutch, and 'pleaded for freedom of religion and national unity' (Paas 2004:251). The Synod of Dordt took place during the reign of Maurice, the Prince of Orange (1567-1625), who succeeded William of Orange (Freist 2012). Similarly significant, the event also took place in the aftermath of the Peace of Westphalia, 'which brought an end to the Eighty Years' War between Spain and the Netherlands (1568-1648), then the Dutch Republic [became] internationally recognized as an independent state' (Freist 2012).

According to Cruz (2008:3-22), The Netherlands had a long tradition of self-government: 'Privileges, liberties, and rights were the cornerstones of Dutch political vocabulary.' Furthermore, The States General, a representative body, 'protected their rights from encroachment by absolutist-minded rulers through the establishment ...'. Cruz (2008) also notes that:

\footnotetext{
... the juxtaposition of privileges and rights with liberties is indicative of a concept of liberty that was not necessarily the same as that espoused by classic republicans, civic humanists, or late Enlightenment thinkers. (p. 14)
} 
Cruz (2008:3-22) further asserts that, 'the Dutch did not perceive the essence of liberty as personal liberty, but rather as the absence of tyranny ...'. For the Dutch, 'the essence of citizenship was the possession of rights, whereas in the republican vocabulary the essence of citizenship was participation' (Cruz 2008). Thus:

Privileges and rights were the chief means by which liberty could be safeguarded, a principle rooted in the philosophy of neo-Stoicism, not Renaissance republicanism, and one pioneered by the Dutch. (Cruz 2008:14)

It was in this context that the teachings of Jacobus Arminius (1560-1609) about Calvinistic doctrine of predestination and the sovereignty of God gained grounds in the Netherlands.

The Synod of Dordt, which took place from 13 November in 1618 to 6 May 1619 in The Netherlands, was convened by the Dutch government to find a lasting resolution to the Arminian controversy that had unsettled the church for about two decades (Sinnema 2011). The Synod was the international meeting of Reformed theologians where the views of Jacobus Arminius and his followers were condemned' (Van Lieburg 2011:1-19). Leonard Verduin (1962) notes that:

... the Great Synod met in a climate in which idea that God is sovereign was under fire; a theology threatened which if allowed to go unchastened would lead to the blasphemous notion that God loses His sovereignty and loses it to man! (pp. 4-7)

It was this historic situation, rather than anything inherent in the Reformed system, that determined Dordt's emphasis.

\section{The role of Scripture and scholastic tradition}

According to Sinnema (2011:313-334), the Synod had a mandate from the States General of The Netherlands to the delegates binding them by oath to base all their deliberations on 'the word of God alone as the sure and undoubted rule of faith, and not any human writings'. In spite of the order to use only Scripture in dealing with the Arminians' challenge, scholars have uncovered a synthesis of philosophical treads that were at work in the deliberations. Henri Krop (2011:50), for instance, notes that 'a significant number of delegates at the Synod were professional philosophers' with diverse views. Van Asselt (2007:203-210) affirms that these theologians and their opponents were influenced by the Scholasticism of the 14th and 16th centuries whose roots extended far back to and was spurred by Augustine's antiPelagius writings on grace and predestination. In other words, the appeal to Scripture only justified their preconceived notions that were already rooted in scholastic thought.

Krop (2011:52) notes that 'the delegates' [desire] to overcome discord in the Reformed Churches by including in the canones a range of views on the basis of some basic philosophical - and theological - truths'. Fred Klooster (2008) further asserts that:
The appeal of the Canons is to Scripture, and this appeal is pervasive throughout ... This doctrine the Synod judges to be drawn from the Word of God, and to be agreeable to the confession of the Reformed Churches. (p. 114)

Behind the insistence on application of the 'pure' Word of God lay the assumption that they tried to re-establish 'pure' religion versus 'impure' or 'false' doctrines of the Remonstrants.

\section{Divine sovereignty and human responsibility}

According to Klooster (2008:114), 'The central issue [was] the divine sovereignty and human responsibility; another way of putting that is that it involves differing views of God and man.' Verduin (1962:4-7), in defence of divine sovereignty, states the issue more strongly: 'At the Synod of Dordt men talked very seriously about divine sovereignty and drew up canons that were to secure the doctrine of divine sovereignty for coming generations.'

In dealing with this issue, however, according to Van der Walt (2011:505-538), Dordt's proceedings commenced on the premise of an 'All-determining God', and the discussions operated along two principal methods. Theological discourse followed 'the synthetic (a priori) method, which argued from causes to their consequences ... from God to the cosmos' (Van der Walt 2011:505-538). Then the second, 'the so-called analytical method (for "ordinary" believers)' took the opposite direction, 'from the effects backwards through inter-mediary causes and ultimately to the final cause, God' (Van der Walt 2011:505-538).

Nonetheless, according to Van der Walt (2011), theological interpretation and application of Scripture was informed and driven by some philosophical assumptions of the period. The Calvinists and Arminians tried to harmonise and accommodate Aristotelian and Platonic philosophy and 'contemporary early Rationalism with Scripture' (Van der Walt 2011:505-538), the latter considered as a text for doing theology. Consequently, divided loyalty between these approaches meant that their theologies failed to provide clear theological guidelines. This 'complex synthesis' in Van der Walt's view (2011:505-538), was achieved by following two methods: The first one involved 'eisegesis-exegesis', the method which read alien ideas into a 'biblical text', 'and then read such ideas out of the Scriptures' - with biblical justification. The second method entailed 'nature-supernature (or grace) ... Its consequence was a compromise between what can be believed and reasoned - be-tween theology (as the queen) and philosophy (as merely a servant to theology)' (Van der Walt 2011:505-538). Consequently:

\footnotetext{
... the Synod of Dordt [was] not so much a demonstration of rigid and austere Calvinism ... it was 'an expression of the delegates' desire to overcome discord in the Reformed Churches by including in the canones a range of views on the basis of some basic philosophical - and theological -truths. (Krop 2011:52)
} 


\section{The role of the Holy Spirit in salvation}

\section{The [Holy] Spirit of God in relation to the [Word]}

The role of the Holy Spirit featured prominently at the Synod of Dordt; precisely, in relation to the notions of rebirth, predestination and salvation (Krop 2011:107-133). Beyer and Penman (2011:107-133) narrate the story of a Danish woman, a British resident, Anna Walker, who claimed that the Holy Spirit had inspired her to attend the Synod. However, her presence did not in any way, influence the theological discussions or activities at Dordt (Krop 2011:107-133), nor did it deter Dordt from discussing the Holy Spirit primarily in relation to the doctrines of divine election, sovereignty, human will and salvation. The discussion about the role of the Holy Spirit at the Synod of Dort has been presented in the document, De Dordtse leerregels dichterbij gebracht Article 11' (Koop 1983). ${ }^{1}$

\section{The Holy Spirit in the work of salvation}

Article 11 of Dordt is a case in point. The Dordt fathers assert that:

When God executes his good pleasure in those chosen ones and realizes the true conversion in them, then He not only allows them to hear the Gospel through the preaching and so greatly illuminate their minds through the Holy Spirit, that they understand well and discern what God's Spirit learn their will. But He also penetrates into the Spirit, which works rebirth, $\mathrm{He}$ opens the closed heart, He softens it, He circumcises the uncircumcised. (Koop 1983:121-125)

In this regard, the Holy Spirit is an instrument of God the Father in the history of salvation. The Spirit is an enabler and medium in the process of mediating the gospel of salvation and the one who prompts the 'elect' to respond positively to the gospel of salvation. 'He renews the will, of death makes He alive, of shows good, of reluctant willing, of unruly obedience' (Koop 1983:121-125). The Holy Spirit, in relation to the Word, plays an important role in the election of humankind.

The Lord God has decided in his sovereign good pleasure to choose a certain number of people for salvation. This decision by God is carried out in time. In that embodiment, he uses the Word, the gospel, that he preaches. He ensures that the elect receives the gospel. 'The Holy Spirit goes to that preaching of the Word to light their understanding so that they understand the Word and understand the call ...' (Koop 1983:121-125).

It is the Holy Spirit that unveils God's Word to humans, illuminates the minds and sensitises humans to respond to God's grace. In this way, the Holy Spirit plays an important role in election. The Spirit prompts humans to collaborate with God in the drama of salvation. Thus, the work of the Holy Spirit initiates regeneration; it operates in the process of 1.All information in this section derives entirely from this source. rebirth and renewal. The Holy Spirit is a force - the power through which humans are recreated - hence, they are able to partner with God. Furthermore, the Lord brings the chosen ones further. The Holy Spirit also goes through the gospel to the depths of a person, to the centre, to the heart. Thus, the Spirit brings man to repentance, to rebirth. For the Word of God - by which the Holy Spirit works - is living, powerful and sharper than a double-edged sword. It penetrates so deeply that it separates soul and spirit (Heb 4:12).

The Holy Spirit inspires the gospel (the Word) to draw human beings towards God. It is the power that brings radical transformation to the life of a believer. Through the Holy Spirit, the Word of God has the power to bring judgement and mercy to the believer. The implication of this view is that the Holy Spirit is a missionary agent in the salvation of humankind. Salvation is impossible without the dynamic activity of the Spirit in the life of a believer. The Spirit enables the believer to experience the saving grace of God on which he or she is totally dependent.

\section{Personal assurance of salvation}

Robert Godfrey (2011:243-260) discusses some theological dimensions of the Canons of Dordt which derive from their characteristics. He (Godfrey 2011:255) identifies the link between salvation and personal growth in the faith as reflected in the Canons, which teach that, 'Assurance grows as Christians see the fruit of salvation in themselves', and this is 'pointed out in the Word of God'. More significantly, assurance is linked to the role of the Word of God and the Holy Spirit in salvation. Godfrey (2011) cites Article 10 as the basis for this point and identifies the three sources of assurance:

This assurance, however, is not produced by any peculiar revelation contrary to, or independent of the Word of God, but springs from faith in God's promises, which he has most abundantly revealed in his Word for our comfort; from the testimony of the Holy Spirit, witnessing with our Spirit, that we are children and heirs of God (Romans viii. 16); and, lastly, from a serious and holy desire to preserve a good conscience, and to perform good works. And if the elect of God were deprived of this solid comfort, that they shall finally obtain the victory, and of this infallible pledge or earnest of eternal glory, they would be of all men the most miserable (V, 10). (p. 255)

Godfrey (2011:255) concludes that, 'in pointing to these three sources of assurance the Synod was taking a standard Reformed approach'. However, as will be discussed later, this standard Reformed principle becomes important when we consider Pentecostal theological perspectives on personal salvation and God's promises as declared in the Scriptures. However, beyond Godfrey's assertion, it is significant to note that there are 'Pentecostal-like' perspectives in the Canon. The Canon stresses the link between God's promises, the Word of God and the Holy Spirit. Faith in God's promises is a cardinal principle which stands squarely on the assurance of God's act of saving faith. Similarly, individual salvation and assurance are critical to understanding election. There is almost a triumphant overtone about this theological perspective. 


\section{Grace and election}

Godfrey (2011:256) argues that another 'implication is the importance of the means of grace in the church for the individual Christian'. In his view (Godfrey 2011), this is closely intertwined with the:

Promise of the gospel ... that whosoever believeth in Christ shall not perish, but have eternal life ... to be declared and published to all nations, and to all persons promiscuously and without distinction, to whom God out of his good pleasure sends the gospel. (p. 256)

In other words, the proclamation of the gospel is the means of grace. The gospel is promised to all nations, because it derives from the grace of God. Humankind is assured salvation by the grace of God through the proclamation of the gospel.

However, the doctrine of grace and election at Dordt must be placed within a theological-historical framework (Van Asselt 2007:203-210), for 'The refutation of errores and canons are [sic] part of a long tradition of biblical interpretation and doctrinal development ...' which is subsequently traceable to a school of thought in the 14th and 16th centuries that was 'inspired by Augustine's anti-Pelagius writings' on grace and including the acceptance of the doctrine of double predestination'.

Van der Walt (2011:505-538) further argues that Dordt held a static view of election. While there was no dispute at Dordt that the cosmos was the creation of God, it was viewed as static, pre-determined by an all-determining God. This view did not have room for or acknowledge the progressive nature of creation or human responsibility in creation. According to Van der Walt, this view placed humans at the mercy of the divine sanction. Effectively, it encouraged human capitulation to the all-powerful God (Van der Walt 2011:505-538). It was deterministic (Van der Walt 2011):

They thought cosmologically and could, therefore, not fully acknowledge the genesis, development of creation, or the cultural task God gave man to fulfil his responsibility in unfolding the potential of creation. (pp. 505-538)

Consequently, their conception of God and humankind hampered human responsibility; 'It encouraged passivity, quietism, resignation, the acceptance of a preordained divine resolution' (Van der Walt 2011:505-538).

\section{Indigenising the reformed faith}

From another perspective, the Synod of Dordt could be seen today as an attempt to give expression to the Reformed faith and doctrine of the sovereignty of God in the national psyche of the Dutch nation. It was an attempt to 'incarnate' the Reformed faith on the Dutch soil. The Synod sought to plant the Reformed faith in the national character and ethos of the Dutch. From different perspectives, several scholars stressed what they saw as the nationalistic and providential dimensions of the Synod.
For instance, Jan Kuiper (1865-1943), a mainstream orthodox member of the Hervormde Kerk, positively assessed the Synod, saying:

People regarded it as the completion of the work of the Reformation, while others, who did not subscribe to the Reformed truth, were unable to find words bitter enough to disparage its work and discredit it. (in Van Eijnatten 2011:418)

The impression given is that the Synod was almost equal in significance as Luther's Reformation in Germany. In other words, the significance of the Synod finds a parallel in Luther's Reformation in Germany. Whereas the Germans started the Reformation, the Dutch finalised it. Thus, Kuiper concludes that the Synod of Dordt '... was ineradicably ingrained in [Dutch] consciousness. It was an event into which they were inescapably bound, if not by faith, then at least by nationhood and history' (in Van Eijnatten 2011:418).

However, these scholars seemed to view this episode in the national history of the Netherlands as part of the broader scheme of things in the salvation history of humankind. In this respect, national history reflected the broader movement of salvation history. Thus, Arentius Hendricks Nieboer (1869-1929), a separatist minister of the 1886 schism, stated that the Synod of Dordt showed that Calvinism 'was suited exactly to the nature, character and needs of our people ... an event of national importance' (in Van Eijnatten 2011:418). Nieboer concluded that it showed the greatness of their forefathers and not only was it embedded in the national consciousness, but it was also providential (in Van Eijnatten 2011:420-421). In other words, the Synod signified that the Dutch were a chosen nation. Thus, this important religious event seemingly had religious ideological overtones.

In response to some adverse assessment of the Synod in 1914, Hendrik Kaajan (1879-1940), an Orthodox minister, highlighted the significance of the Synod which 'unilaterally defended the sovereignty of God ... it had ended civil and religious discord and "saved the unity of the nation"' (in Van Eijnatten 2011:419-420). Rolf Hendrik Bremmer (1917-1995), a minister and church historian of another Orthodox separatist church, viewed the 16th century territory of the incipient national state as the 'native soil' from which sprouted the 'Dutch Reformed Churches' (in Van Eijnatten 2011: 419-420). Wigger Meindersma (1872-1964), a minister from the liberal wing of the Hervormde Kerk, saw the '... event $[a s]$ of exclusive national significance ... a necessary phase in the development of Reformed Protestantism,' enabling, 'the Protestant Principle eventually to come into its own' (in Van Eijnatten 2011:419-420).

Undoubtedly, the Synod of Dordt was a landmark in the history of the Netherlands. The Canons of Dordt presented to the Dutch nation another confessional statement, designed to 'purify' and 'unify' the Reformed Faith. Clearly, the Dutch seemed to view the event in much similar manner that the Germans saw the Lutheran Reformation. In the eyes of the Dutch, while the Reformation had been initiated in Germany, 
it was in the Netherlands that its principle was reaffirmed. Thus, the Synod of Dordt was an attempt to indigenise the faith, to give expression to the principles of the Reformation on Dutch soil.

\section{Dordt-Calvinistic tradition in South Africa}

Jan van Riebeeck landed at the Cape Colony on 06 April 1652 with the mandate to fulfil a special requirement stipulated by the Dutch East India Company (DEIC), which was 'the need for the "Reformed Christian religion" to be promoted in the settlement' (Cilliers 2013:1-16). Therefore, Van Riebeeck officially opened 'the first meeting of the Council of Policy with a prayer that echoed the DEIC's stipulation', which is that the 'true Reformed Christian Doctrine' be spread among 'these wild insolent people' (Cilliers 2013:1-16). The Reformed faith was considered universalistic, and it had to be indigenised in Southern Africa. Thus, the Dutch Reformed faith arrived in Africa and, over time, some of its traditions would germinate in the fertile soil of Southern Africa.

\section{The Pentecostal influence of Andrew Murray}

The nascent links between Dordt and Pentecostal, and African traditions in Southern Africa can be traced to Andrew Murray, a Scot and a Dutch Reformed minister. According to Hollenweger (1972), Murray was ordained together with his brother, John, in the Reformed Church in the Netherlands in 1848. Andrew Murray was then sent to the Cape in 1908, already having had some Pentecostal experience in Europe (Hollenweger 1972). Hollenweger (1972:111-125) reports the dramatic impact of Murray's 45 years of ministry in Wellington and later in Bloemfontein where his ministry also had considerable impact on the local people.

Much like Dordt, Murray believed in the role of the Holy Spirit in effecting salvation, in convicting believers of sin (Hollenweger 1972:111-125). Hollenweger (1972:111-125) offers details of Murray's Pentecostal experiences and the influence of his ministry in Wellington, in the Cape and in Bloemfontein, which apparently touched Piet le Roux. According to Hollenweger (1972:111-125), Murray's biographer, Alfred Stucki, reports that Murray followed a fundamentalist approach to Scriptures, and tried to apply and order his life and ministry on the precepts of the Bible as the true Word of God.

\section{Piet le Roux: A bridge to South African Pentecostalism}

There is no record that Murray himself ever joined the Pentecostal Church in South Africa. However, the role of his disciple, Piet le Roux, another minister in the Dutch Reformed Church, provides an important link to the development of the Pentecostal movement and by extension, African Pentecostal traditions in South Africa. Anderson and Hollenweger (1999:90) note that in 1902, Le Roux was working at Wakkerstroom in Mpumalanga Province, and in
1902 or 1903, together with some 400 African coworkers, joined the Chicago-based Zion movement founded by John Alexander Dowie.

\section{The role of the Pentecostal American Missionaries}

In 1904, Dowie sent Daniel Bryant to South Africa, where Bryant initially baptised 141 members in Wakkerstroom including Le Roux (Anderson 1999:90). By 1905, the members of his congregation had increased to 5000. It was from this root that the whole series of Zion and the Apostolic African Independent Church eventually emerged (Anderson 1999:91). At that time, Wakkerstroom was to South African Pentecostal churches what Azusa street revival in Los Angeles was to the worldwide Pentecostal movement. There, Le Roux experienced 'baptism in the Holy Spirit in 1907' (Anderson 1999:90).

The arrival of two American Pentecostal missionaries, Thomas Hezmalhalch and John G. Lake in 1908, gave further impetus to the Pentecostal movement in South Africa. These missionaries had connections to the Azusa street revival under the black preacher, William Seymour, as well as with the 'Zion movement in Chicago. Le Roux, upon realising his spiritual hunger, for Zion taught immersion and divine healing, but not Pentecost,' joined Lake's movement, now called the Apostolic Faith Mission (AFM). However, from this point the Zion Apostolic Church, largely black-dominated, established itself as a distinct strand within the Pentecostal movement (Hollenweger 1972:111-125).

\section{African initiated churches - Indigenising Pentecostalism}

Unlike the white-dominated Pentecostal stream, the Zionist movement has given birth to African Independent Churches of various shades. Within the Zionist Apostolic Churches, there emerged further formations - identified by scholars as the African Independent or Initiated Churches (AICs). Among prominent leaders in the latter are Daniel Nkonyane, Elias Mahlangu of Zion Apostolic Church of South Africa, Nicholas Bhengu, and Engeans Lekganyane, (1885-1948), founder of the Zionist Christian Church, who met Le Roux in Johannesburg in 1908 when the latter healed and baptised him in the Spirit. Besides other common features such as the emphasis on the experience of the Holy Spirit, both branches tend to be optimistic in their attitude to the idea of personal salvation:

The doctrine of the Spirit, or pneumatology, occupies the central place in the majority of the so-called African Independent churches ... in Southern Africa, where their church members constitute up to $40 \%$ of the black population ... (Hollenweger 1972:126-148)

These traditions claim personal assurance of salvation and have a triumphalist outlook on life, which causes them to lay emphasis on transformation of own personal circumstances. From a doctrinal point of view, these churches ought to be 
viewed as standing in the Reformed tradition similar to that of Luther and the Synod of Dordt, or as Anderson (2008) has observes:

... this form of Christianity can be called the 'African Reformation' of the 20th Century, for successive waves of Pentecostalism in the twentieth century have fundamentally altered the shape of African Christianity. (pp. 1-42)

\section{Some Dordt traditions in the Pentecostal/African traditions The role of the Word}

As noted above, Sola Scriptura was claimed as the cardinal rule in the adjudication of the writings of the Arminians at the Synod of Dordt. The presupposition was that Scripture was the 'pure' Word of God in contrast to 'human-made' traditions which, at that time, were practiced in the Roman Catholic Church. Today, one of the criticisms that scholars have raised against Dordt, is precisely on this point. For instance, Meindersma argued that 'Theologically, the Synod [of Dordt] represented an obsolete, Bible-centred approach to faith' (in Van Eijnatten 2011:419).

In a similar vein, Van der Walt (2011) characterised Dordt's methodological approach as biblicism - a literal interpretation and justification of a priori held views about Scripture. Nonetheless, Dordt's position of Sola Scriptura was significant, because it established the Protestant principle.

The underlying assumptions held by the Synod of Dordt that the Scripture is the true Word of God, is the very same principle which binds nearly all Pentecostal churches. In this way, their approach to the Bible is biblicist, literally believing it to be the Word of God. Thus, Hollenweger (1972) asserts that:

ALMOST all Pentecostal denominations and holiness groups teach: The Bible is the inspired word of God and its content is infallible divine revelation. [It] is the infallible rule of faith and conduct, and is superior to conscience and reason, but not contrary to reason. (p. 291)

The testimony of the Pentecostals, 'We believe in "the whole Bible"', is regarded as a confessional creed in the Pentecostal churches (Hollenweger 1972:517).

In Southern Africa, many Pentecostal churches and the African Independent Church formations and groups follow this fundamentalist approach to Scriptures, for instance the Pentecostal congregation of the well-known pastor, Nicholas Bhengu (Hollenweger 1972:517). Similar to the literalist approach of the Dordt fathers, Bhengu took a fundamentalist stance on Scripture. Scholars of African Christianity categorise these churches as 'Spirit' churches because of their emphasis on the experience of the Holy Spirit in the life of the believer.

Anderson (2015) has identifies notable characteristics and features of these churches noting that: the new Spirit churches created by Africans in the early twentieth century used the Bible verses to justify their practices and found new prohibitions there that were taken literally, from the Old Testament in particular. (p. 64)

While Dordt condemned the Arminians on theological grounds, these churches condemn some African practices with similar biblical authority to Dordt. Anderson (2015) further notes that:

But for this reason, too, African churches often rejected witchcraft, magic and ancestor rituals as a means of solving problems ... In the vernacular Bible, Africans [have] an independent source of authority abounding in symbolic healing and exorcism practices not unlike their own. (p. 64)

It seems as if, in condemning these practices, the Pentecostals seek to 'purify' African Christianity from what they see as evil cultural practices, perhaps much like the Dordt Fathers perceived that they were 'purifying' the Reformed faith from its corrupters.

\section{The Holy Spirit - Agency in salvation}

As already noted, the role of the Holy Spirit featured prominently at the Synod of Dordt in relation to the doctrine of election and divine salvation of humankind in history. Specifically, Dordt considered the role of the Holy Spirit in testifying to the believer about God's salvation, that is the Holy Spirit's role in the illumination of the mind of the believer to enable him or her to receive the Word. For the Dordt Reformers, the Holy Spirit not only allows them to hear the gospel through the preaching and greatly illuminate their minds so that they understand and discern God's will, it is also responsible for rebirth. Through witnessing, the Holy Spirit assures the elect of their identity as the children of God.

On the role of the Holy Spirit in salvation, the Synod of Dordt took a fundamentalist approach, albeit expressed within the rationalism and scholastisicism of the day. In line with Dordt, the Pentecostals in Southern Africa also take a fundamentalist approach to Scriptures, but for them, the role of the Holy Spirit is more than a rational issue; it is a pragmatic issue. Not only do they believe that the Holy Spirit must be made manifest in the lives of the believers, but they also claim to experience the Spirit's manifestation and power in their lives. Thus, Anderson (2001) asserts:

The common characteristics shared by African churches of the Spirit and other Pentecostals are obvious ... Both have an emphasis on the active and manifest presence of the Spirit in the Church. They have gone a long way towards meeting physical, emotional and spiritual needs, offering a solution to all of life's problems and a way to cope in a threatening world. (pp. 98-119)

Marius Nel (2018) puts it more succinctly:

While Protestants emphasise orthodoxy (correctness in doctrine and confession as derived from Scripture), Pentecostals stress orthopraxy. They do not deny the importance of doctrine being founded on the Bible but they seek validation of doctrinal truth 
in dynamic activity in the Spirit. In their preaching, they do not primarily aim at communicating doctrinal truths but to minister to the spiritual, physical, psychological and social needs of the people assembled to meet the Word, Jesus Christ. (pp. 1-9)

Anderson (2001) affirms that:

The stress on the Holy Spirit in practical living experience links the two traditions [AICs and Pentecostals]. The adherents of both traditions stress the manifestations of the Holy Spirit in the life of the believer. In addition to this, however, as it has been noted earlier, their fundamentalist stance with regard to the Scriptures seem to be a common bond of unity ... (pp. 98-119)

Even though her prophecies were never entertained at Dordt, the spirituality of Anna Walker (mentioned above) would have resonated with the Pentecostal spirituality and tradition in South Africa today. Thus, just as Dordt believed it was on the side of truth, so do Pentecostals today believe that they stand on the truth of the Scriptures.

The Dordt fathers saw salvation - the salvation of the soul, liberating a believer from this terrible world of sin, in individualistic terms. This spirituality tended to be 'otherworldly' in orientation. Even though the Pentecostals also stress the individualistic approach to salvation, 'Salvation in Pentecostal discourse encompasses the body, soul, and the spirit and is simultaneously about wellbeing here and now and in the afterlife' (Wariboko n.d.). However, for certain black African Pentecostals in Southern Africa, in contrast to Dordt and other international Pentecostal groups today, the role of the Spirit takes a broader cosmic dimension. Ancestors are accorded a critical role in unravelling critical questions of life, health, misfortune and suffering in the life of a believer. Thus, alongside God, Jesus and the Holy Spirit, the ancestors are regarded as playing an important role in the ordering of and integration of life (Anderson \& Otwang 1993).

Finally, we have noted that scholastic philosophy guided the biblical hermeneutics by the Dordt fathers, as the Bible was used to justify their condemenation of the Arminians. In Southern Africa, the Pentecostal approaches to the Bible seem to be free of intellectual assumptions. As Marius Nel (2016:1-9) notes, Pentecostalism in South Africa, as elsewhere in the world, is neither intellectual nor antiintellectual. It tends to live with tension in this regard. Even though the context in the 21st century Southern Africa is far removed from that of the 17th century Dordt in the Netherlands, how biblical hermeneutics engages with the issue at hand, remains critical. The Canons of Dordt may have very little relevance to the Pentecostal mind in Southern Africa today. However, the role of the Scripture in engaging with critical issues, remains relevant.

\section{Conclusion}

This article has sketched a background to the event of the convention of the Synod of Dordt in 1618-1619, highlighting some of its critical teachings and features, namely the role of Scripture and scholastic tradition, divine sovereignty and human responsibility in salvation within the framework of scholastisicm and biblical framework. Similarly, the article examined Dordt's perspectives on the role of the Holy Spirit, in relation to election and salvation as well as to personal assurance of salvation. Lastly, the article considered the Canons of the Synod of Dordt an attempt to give expression to the Reformed faith in the Dutch nation. More importantly, this article highlights some common features and critical points of dismilarities between the Pentecostal traditions and African 'Spiritual' Churches in South Africa today. To some extent, the Pentecostal and African 'Spiritual' Churches today are a legacy of the Reformed traditions shaped in Europe. As Krop (2011) has states:

... the Synod of Dordt [was] not so much a demonstration of rigid and austere Calvinism ... [it was] an expression of the delegates' desire to overcome discord in the Reformed Churches by including in the canones a range of views on the basis of some basic philosophical - and theological - truths. (p. 52)

\section{Acknowledgements Competing interests}

I declare that I have no financial or personal relationships which may have inappropriately influenced me in writing this article.

\section{Author's contributions}

I am the sole author.

\section{Ethical consideration}

This article followed all ethical standards for carrying out research without direct contact with human or animal subjects.

\section{Funding information}

This research received no specific grant from any funding agency in the public, commercial, or not-for-profit sectors.

\section{Data availability statement}

Data sharing is not applicable to this article.

\section{Disclaimer}

The views and opinions expressed in this article are those of the author and do not necessarily reflect the official policy or position of any affiliated agency of the author.

\section{References}

Anderson, A., 1999, 'Dangerous memories for South African pentecostals', in A. Anderson \& W. Hollenweger, Pentecostals after a century, pp. 90-91, Sheffield Academic Press, Sheffield.

Anderson, A., 2001, 'Stretching the definitions? Pneumatology and 'syncretism' in African Pentecostalim', JPT 10(1), 98-119. http://search.ebscohost.com/login.asp $x$ ?direct=true\&db=rfh\&AN=ATLA0001335972\&site=ehost-live \&scope=site

Anderson, A.H. 2008 'African independent churches and pentecostalism: Historical connections and common identities', Ogbomoso Journal of Theology 13(1), 22-42, viewed 08 January 2019, from http://search.ebscohost.com/login.aspx?direct= true \&db=rfh\&AN=ATLA0001838754\&site=ehost-live \&scope=site 
Anderson, A.H., 2015, 'Stretching the definitions? Pneumatology and "syncretism" in African Pentecostalism', in M. Lindhardt (ed.), Pentecostalism in Africa, pp. 54-74, Brill, Leiden.

Anderson, A. \& Hollenweger, W. (eds.), 1999, Pentecostals after a century, Sheffield Academic Press, Sheffield.

Anderson, A. \& Otwang, S., 1993, Tumelo: The faith of African Pentecostals in South Africa, UNISA, Pretoria.

Beyer, J. \& Penman, L., 2011, 'The petitions of "A supposed prophetess": The Lubeck letters of Anna Walker and their significance for the Synod of Dordt. A lingusitic and contextual analysis', in A. Goudriaan \& F. van Lieburg (eds.), Revisiting the Synod of Dordt (1618-1619), pp. 107-133, Brill, Boston, MA

Cilliers, J., 2013, 'Power, space, and knowledge: Theological-aesthetical perspectives on Michel Foucault's contribution to post-colonial theory', paper presented at the Summer School, Humboldt University, Berlin on the theme Postcolonial Theories as a Challenge for Theology, 28th May-2nd June.

Cruz, L., 2008, 'Turning Dutch: Historical myths in early modern Netherlands', Sixteenth Century Journal XXXIX(1), viewed 14 April 2019, from https://www.jstor.org/ stable/20478749?seq=1\#metadata_info_tab_contents

Freist, D., 2012, 'The Dutch century', in D. Freist (ed.), European History Online (EGO), pp. 1-54, Leibniz Institute of European History, viewed 23 February 2019, from http://www.ieg-ego.eu/freistd-2012-enURN:urn:nbn:de:0159-2012101701

Godfrey, R., 2011, 'Popular and catholic: The modus docendi of the Canons of Dordt', in A. Goudriaan \& F. van Lieburg (eds.), Revisiting the Synod of Dordt (161-1619), pp. 243-260. Brill, Boston, MA.

Hollenweger, W., 1972, The Pentecostals, SCM Press, London.

Klooster, F., 2008, 'The doctrinal deliverances of Dordt', in P. de Jong (ed.), Crisis in the Reformed Churches, pp. 73-119, Reformed Fellowship, Grandville, MI.

Koop, E., 1983, De Dordtse Leerregels dichterbij gebracht, Van den Berg, Kampen.

Krop, H., 2011, 'Philosophy and the Synod of Dordt: Aristotelianism, humanism, and the case against Arminianism', in A. Goudriaan \& F. van Lieburg, Revisiting the Synod of Dordt (1618-1619), pp. 52-133, Brill, Boston, MA.
Nel, M., 2016, 'Rather Spirit-filled than learned! Pentecostalism's tradition of antiintellectualism and Pentecostal theological scholarship', Verbum et Ecclesia, 37(1) a1533. http://dx.doi.org/10.4102/ve.v37i1.1533

Nel, M., 2018, 'Pentecostals and the pulpit: A case study of the Apostolic Faith Mission of South Africa', HTS, Teologiese Studies/Theological Studies 74(2), a4664. https:// doi.org/10.4102/hts.v74i2.4664

Paas, S., 2004, From Galilee to the Atlantic: A history of the church in the West, Kachere Books, Zomba.

Sinnema, D., 2011, 'The Canons of Dordt: From judgement on Arminianism to confessional standard', in A. Goudriaan \& F. van Lieburg (eds.), Revisiting the Synod of Dordt (1618-1619), pp. 313-334, Brill, Boston, MA

Van Asselt, W.J., 2007, 'No Dordt without scholasticism: Willem Verboom on the canons of Dordt', CHRC, 87(2), 203-210, viewed 09 March 2019, from https:// www.researchgate.net/publication/249596685_No_Dordt_Without Scholasticism_Willem_Verboom_on_the_Canons_of_Dordt

Van Eijnatten, J., 2011, 'Making sense of schism', in A. Goudriaan \& F. van Lieburg (eds.), Revisiting the Synod of Dordt (1618-1619), pp. 397-424, Brill, Boston, MA.

Van der Walt, B.J., 2011, 'Flagging philosophical minefields at the Synod of Dort (1618-1619): Reformed Scholasticism reconsidered', Koers 76(3), 505-538. (A revised text from a paper delivered at the Vollenhoven Colloquium on 15 A revised text from a paper delivered at the Vollenhoven Colloquium on 15
August 2011 at the Free University of Amsterdam, the Netherlands, prior to the August 2011 at the Free University of Amsterdam, the Netherlands, prior to the International Symposium
for Christian Philosophy).

Van Lieburg, F., 2011, 'Gisbertus Samuels: A Reformed minister sentenced by the Synod of Zeeland in 1591 for his opinions on predestination', in A. Goudriaan \& F. van Lieburg (eds.), Revisiting the Synod of Dordt (1618-1619), pp. 1-22, Brill, Boston, MA.

Verduin, L., 1962, 'Back to Dordt?', The Reformed Journal 12, 4-7, July/August, viewed 10 December 2018, from http://search.ebscohost.com/login. aspx?direct=true\&d $b=r f h \& A N=A T L A 0001925062 \&$ site=ehost-live\&scope $=$ site

Wariboko, N., n.d., 'Pentecostalism in Africa', Oxford Research Encyclopedias, viewed 22 December 2018, from http://oxfordre.com/africanhistory/view/10.1093/ acrefore/9780190277734.001.0001/acrefore-9780190277734-e-120 